\title{
THE RELATIONSHIPS BETWEEN DIFFERENT FORMS OF IRON AND ALUMINIUM IN SOILS AS INDICATORS OF SOIL-COVER DEVELOPMENT ON INDIA'S CHERRAPUNJI SPUR (MEGHALAYA PLATEAU)
}

\author{
MAREK DEGÓRSKI \\ Institute of Geography and Spatial Organization, Polish Academy of Sciences, \\ Twarda 51/55, 00-818 Warszawa, Poland \\ E-mail: m.degor@twarda.pan.pl
}

\begin{abstract}
The aim of the work described here has been to assess the contents of, and interrelationships between, the different forms of iron and aluminium present in soils, these being treated as indicative of soil-cover development and its contemporary functioning in an area under the very significant impact of atmospheric factors with a periodically endopercolative type of water regime. The area in question was the Cherrapunji Spur area of India, as extending along the southern slope of the Meghalaya Plateau, with its highest annual precipitation totals concentrated during the period of the summer monsoon. Results show how the contents of the different forms of the two elements in soil offer an ideal tool by which to both determine the conditioning present in the palaeo-environments in which given soil covers developed and evaluate the pedogenic processes ongoing currently.
\end{abstract}

Key words: forms of iron and aluminium, leaching and podzolization of soil, Cherrapunji Spur, India

\section{INTRODUCTION}

Numerous studies reveal that, in soils developed on similar lithological material and under similar topoclimatic conditions, increasing age is associated with an ever-greater degree of transformation of iron silicates into oxides of iron (Pokojska 1979; Catt 1988; Arduino et al. 1986; Mokma 1991; Bednarek and Pokojska 1996; WRB 1998, 2006; Degorski 2007). Among other manifestations of these processes is a greater share of total iron content in soil that is in the form of free iron, as well as a lower value for the ratio between amorphous iron and free iron (Schwertmann 1964).

Over time, the contents of the different forms of iron and aluminium in soils have been used to formulate criteria by which diagnostic horizons characteristic for the development of given soil types may be identified, these subsequently proving useful in reconstructing the palaeo-environmental conditions under which given soils arose. Among other things, criteria serving in the identification of diagnostic spodic horizons in podzolic soils have been defined, and determinations made of the intensity of processes of leaching and podzolization, this making reference to the contents of amorphous iron and aluminium in the enrichment horizon (WRB 1998, 2006), the transfer of amorphous iron and aluminium (WRB 1998, 2006), the transfer of free iron (Konecka-Betley 1968; Bednarek 1991), the degree of illuviation (Mokma 1983), the con- 
tent of iron/aluminium humus complexes in the enrichment horizon (Mokma 1983), the ratio between the content of iron/aluminium humus complexes in the humus layer and the diagnostic spodic and sideric horizons (Mokma 1983; Bednarek 1991) and the immobile iron/aluminium humus complexes (Mokma 1983; Degorski 2007).

The work described here has sought to assess the contents of - and interrelationships between - the different forms of iron and aluminium in the soils of an area subject to the very major impact of atmospheric factors and periodically an endopercolative type of water regime, with a view to these serving as indicators of conditions under which soil cover developed in the past, as well as current conditions.

\section{THE STUDY AREA}

The research was carried out in the Cherrapunji Spur area - which extends along the southern slope of the Meghalaya Plateau, some $300 \mathrm{~km}$ north of the Bay of Bengal, and which constitutes the first orographic barrier to moist masses of monsoon air arriving from over the Indian Ocean (Fig. 1). The Plateau extends N-S for some $300 \mathrm{~km}$, and has an average altitude of around 1500 m a.s.1. (Starkel 1996). Thanks to its geographical location and monsoon circulation, this area features the world's highest annual rainfall totals, in the range $8-24,000$ mm per year (Soja 2004; Soja and Starkel 2007). From the lithological point of view, the Plateau is formed mainly of Pre-Cambrian quartzites and gneisses, as overlain by

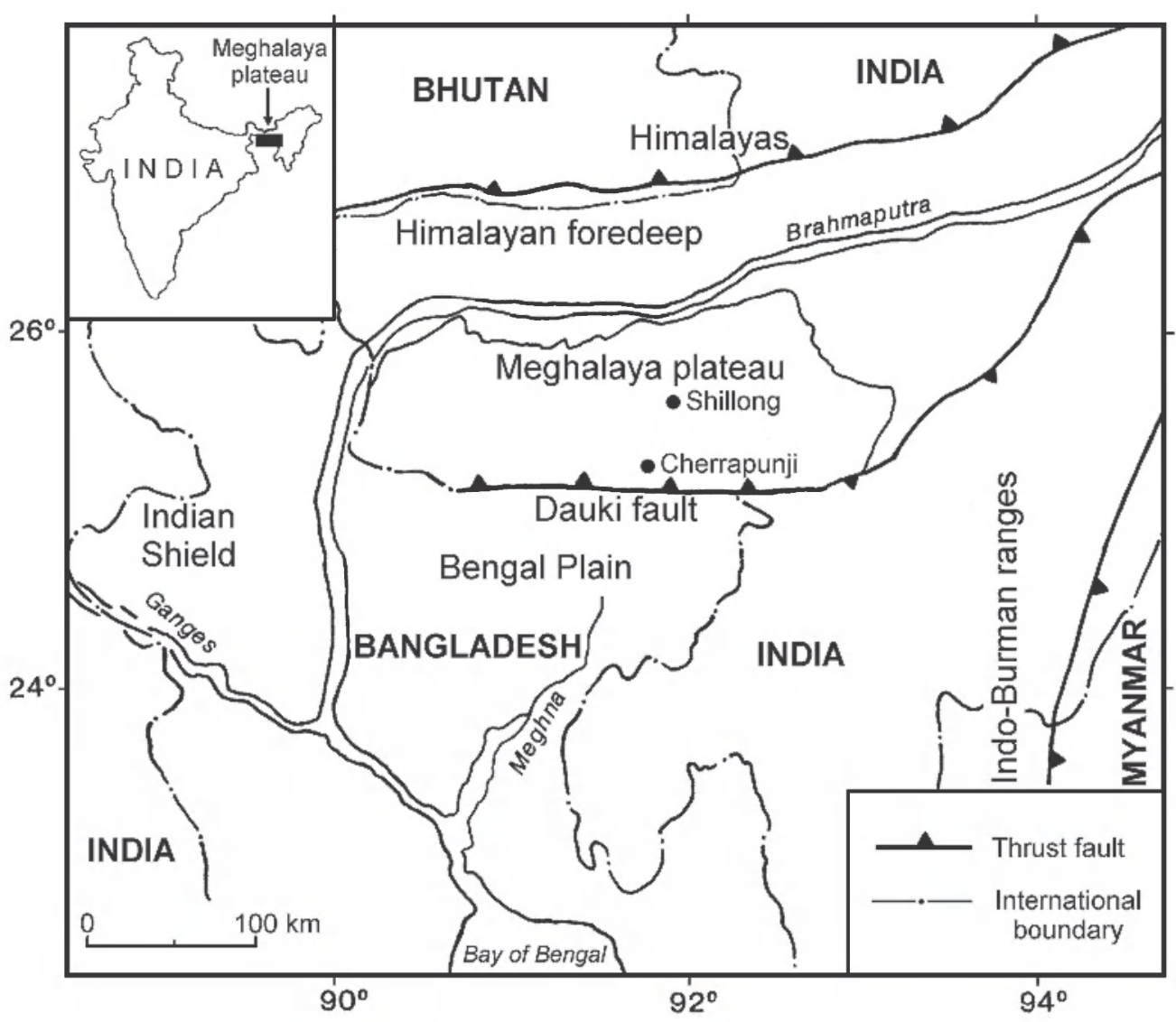

Figure 1. Location of the study area 
younger sediments, mainly sandstones and limestones from the Cretaceous and Palaeogene, as well as diverse denuded and weathered material, first and foremost sandy cover (Mazumdar 1978, 1986; Prokop 2007).

The lithologically varied material of the slope cover is the substratum for the soil cover under study. In the case of that on the Cherrapunji Plateau, the main pedogenic process ongoing is browning (Budek and Prokop 2005), with overlapping leaching, eluviation and podzolization.

\section{METHODS}

In the course of fieldwork done in November 2005, soil material from five research plots was collected. Two of these were on the slopes of the Cherrapunji Spur, the other three on the alluvial plain. In each area, for the one defined types of soil, ten soil profiles was determined and provided samples that were then mixed together to represent the same soil genetic horizons, these then being subject to laboratory research to determine such physical and chemical properties as: soil grain-size distribution - by sieving, as well as via the hydrometric method from Bouyoucos as modified by Casagrande and Prószyński; content of organic carbon $(\mathrm{Ct})$ in horizons of the ectohumus - by Alten's method, and in mineral horizons by a modified version of Tiurin's method; organic carbon following sodium pyrophosphate extraction (Cp) using a SHIMADZU automatic carbon analyser; reaction $\left(\mathrm{pH}_{\mathrm{H} ? \mathrm{O}}\right)$, as determined potentiometrically; content of $\mathrm{CaCO}_{3}$ by Scheibler method, total nitrogen $(\mathrm{N})$, by a modified Kjeldahl method; exchangeable cations $\left(\mathrm{Ca}^{2+}, \mathrm{Mg}^{2+}, \mathrm{K}^{+}, \mathrm{Na}^{+}\right)$, following extraction of samples in $1 \mathrm{M}$ ammonium cetate at $\mathrm{pH} 6.8$ and the ASA method; hydrolytic acidity (HH) - by the Kappen method; iron (Fep), aluminium (Alp) and carbon (Cp) associated with sesquioxides in humus complexes - in a $0.1 \mathrm{M}$ extract of sodium pyrophosphate using the method from McKeague (1981); total iron (Fet) - using the method of sample digestion in hydrofluoric and per- chloric acids; amorphous iron (Feo) and aluminium (Alo) - in an extract of Tamm's (oxalate) reagent (Van Reeuwijk 1995); and free iron (Fed) from a citrate-dithionite extraction following the method of Mehra and Jackson (1960).

The results were also used in calculating: total exchangeable base cations (S) - i.e. the sum of $\mathrm{Ca}^{2+}, \mathrm{Mg}^{2+}, \mathrm{K}^{+}$and $\mathrm{Na}^{+}$; degree of saturation of soils with base cations (V) as $\mathrm{S} / \mathrm{T} \times 100 \%$; content of inorganic forms of iron (Feac) - as Feo - Fep; content of inorganic forms of aluminium (Alac) - as Alo Alp; content of silicate forms of iron (Feas) - as Fet - Fed; and content of non-silicate crystalline forms of iron (Fecr) - as Fed Feo.

The results obtained for the contents of the different forms of iron and aluminium were used in calculating such selected indicators of litho- and pedogenesis as: iron oxide mobility (Schwertmann 1964) - i.e. Feo-Fed ${ }^{-1}$; the content of crystalline forms of iron in the total content of iron (Bednarek and Pokojska 1996) - i.e. (Fed - Feo)Fet ${ }^{-1}$; the content of amorphous iron and aluminium in the enrichment horizon, after the WRB (1998) - i.e. Alo+0.5Feo; the transfer of amorphous forms of iron and aluminium, after the WRB (1998) i.e. $(\mathrm{Alo}+0.5 \mathrm{FeoB}) \cdot(\mathrm{Alo}+0.5 \mathrm{FeoE})^{-1}$; the transfer of free iron, after Konecka-Betley (1968) and Bednarek (1991) - i.e. FedB FedE ${ }^{-1}$; the index of illuviation (Wi) after Mokma (1983) - i.e. $\Sigma_{\text {氵 }}$ Cp Alp Fep $-\sum_{\text {i: }}$ Cp Alp Fep; iron-aluminium-humus complexes in the $\mathrm{B}$ horizon, after Mokma (1983) - i.e. Cp,+Alp+Fep; relationships ongoing between the contents of iron-aluminium-humus complexes in the humus horizon and the diagnostic spodic horizon after Mokma (1983) and Bednarek (1991) i.e. $(\mathrm{Cp},+\mathrm{Alp}+\mathrm{FepB}) \cdot(\mathrm{Cp},+\mathrm{Alp}+\mathrm{Fep} \mathrm{A})^{-1}$; and characteristics of immobile complexes in the B horizon after Mokma (1983) - i.e. $\mathrm{Cp} \cdot(\mathrm{Alp}+\mathrm{Fep})^{-1}$.

Soil typology is according with Soil Taxonomy (1999) but symbols of soil horizons are connected with Polish classification (Systematyka Gleb Polski, 1989). 


\section{RESULTS}

\section{GENERAL CHARACTERISTICS OF THE SOILS STUDIED}

The soils under study here have developed in lithological material of the grain size of weakly-clayey or clayey sands, as well as sandy clays and light clays. In the lighter substratum, irrespective of land-cover type (grassland or forest), it is red- and yellow podzolized soils (Ultisols) that develop, while a greater richness of silty and loamy fractions is associated with podzolized acid brown soils (Inceptisols) and grey-brown podzolized and silty soils with a distinct $\mathrm{Bt}$ horizon (Alfisols). These are also characterised by varying thickness. The thickest (with a solum exceeding 1 metre) are the Ultisols that have arisen from denuding cover shifted on to old sediments of the Eocene limestone tableland. Then there are the Inceptisols, reaching thicknesses of between 80 and 100 $\mathrm{cm}$, and developed in the study area on superficially much-weathered alluvial material. The least thick of the soils studied are in turn the Alfisols, which have developed on weathered sandstone covers.

All of the studied types of soil are characterised by organic and humus horizons with a very acid or acid reaction ( $\mathrm{pH}$ 3.9-5.4), this changing to slightly acid in the eluvial and illuvial horizons of Ultisols and Alfisols (pH 5.8-6.2) and to neutral (pH 6.6-7.2) in the parent rock. Where the geological substratum has developed on Eocene limestone tableland there is an alkaline reaction $(\mathrm{pH}$ 7.9-8.2). The contents of calcium carbonate $\left(\mathrm{CaCO}_{3}\right)$ in this level - as in other parent rocks of the studied soils - are in the range $22.0-26.4 \%$, depending on the lithological material from which they are developed. The humus and eluvial horizons characterised by a very intensive process of leaching in the rainy season are carbonate-free as far as the mineralogical composition of the substratum is concerned.

A consequence of the fact that illuviation processes are periodically very intensive here is the fact that all analysed soil profiles have very varied levels of base saturation
(V). In the humus and eluvial layers values range between 7 and $20 \%$, while those in the substratum are close to $100 \%$.

The humus layers of the studied soil profiles had contents of organic carbon in the range 5-6\%, cf. nitrogen at $0.8-1.2 \%$. There is only a very narrow range of values for the C:N ratio (between 4.2 and 7.5), this denoting a high level of biological activity in soils, to the extent that not all the nitrogen liberated is actually made full use of by vegetation.

\section{THE CONTENTS OF THE DIFFERENT FORMS OF IRON AND ALUMINIUM IN THE STUDIED SOILS AS INDICATORS OF SOIL PROCESSES}

The role of iron and aluminium as pedogenic elements in the emergence and development of soils is very well documented in literature (Alexandrova 1960: Schwertmann 1964; Blume and Schwertmann 1969; McKeague et al. 1971; Borggard 1976; Bednarek 1991; Bednarek and Pokojska 1996; Giesler et al. 2000; Hess and Lundstrom 2000; Riise et al. 2000; Degorski 2007). While the overall contents of iron and aluminium in soils mainly reflect the degree to which the parent rock is rich in these elements, the content of mobile (non-silicate) forms, as well as of the crystalline oxides, are capable of characterising the course of the soil-generating process, its intensity, and the environmental conditioning under which the process has taken and is taking place (Fridland 1957; Petersen 1976; Mokma and Buurman 1982; Melke 1997; Giesler et al. 2000; Lundstrom et al. 2000, Degorski 2007).

In the soils studied, the total contents of iron (Fet) range between about $21.1 \mathrm{~g} \mathrm{~kg} \mathrm{~g}^{-1}$ in humus horizons of Ultisols to over $79 \mathrm{~g} \cdot \mathrm{kg}^{-1}$ in the substratum of these soils (Table 1). The relevant figures for Alt are $25.6 \mathrm{~g} \mathrm{~kg}^{-1}$ in the humus layer of Inceptisols to $74.5 \mathrm{~g} \cdot \mathrm{kg}^{-1}$ in the parent rock of Ultisols (Table 2). The contents of free iron (Fed) and free aluminium (Ald), i.e. that of a non-silicate nature and not associated with the crystalline structure of silicates, point to the degree of 
Table 1. Content of different forms of iron and relationship between them in the studied Ultisols and Inceptisols

\begin{tabular}{|c|c|c|c|c|c|c|c|c|c|c|c|c|c|}
\hline \multirow{3}{*}{ Soli type } & \multirow{3}{*}{ Ilorizmn } & $\vec{\Xi}$ & $\vec{z}$ & 8 & $\stackrel{c}{a}$ & 总 & ty & 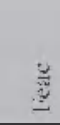 & $\frac{\vec{y}}{\vec{y}}$ & 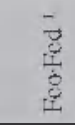 & $\bar{v}$ & $\frac{\vec{b}}{\vec{b}}$ & \multirow{2}{*}{$\begin{array}{l}\frac{5}{3} \\
\frac{1}{8} \\
\frac{1}{8}\end{array}$} \\
\hline & & & & & & 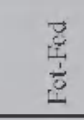 & $\begin{array}{l}\frac{8}{1} \\
\frac{1}{8} \\
-1\end{array}$ & $\frac{c}{\underline{n}}$ & & & & & \\
\hline & & \multicolumn{7}{|c|}{ g.kg ' } & \multicolumn{5}{|c|}{$\%$} \\
\hline \multirow[t]{12}{*}{ Ultisols } & $\Lambda$ & 24.11 & 6.93 & 1.08 & 1.05 & 17.18 & 5.85 & 0.03 & 28.75 & 15,62 & 4.37 & 4.37 & 24.26 \\
\hline & $\mathrm{AE}$ & 23.96 & 10.45 & 1.54 & 1.35 & 13.51 & 8.91 & 0.19 & 47.61 & 14.74 & 5.65 & 5.65 & 37.18 \\
\hline & $13 \mathrm{Fe}|3| \mathrm{r}$ & 26.87 & 11.17 & 2.77 & $2.3 \%$ & 15.70 & 8.40 & 0.39 & 41.56 & 24.80 & 8.86 & 8.86 & 31.25 \\
\hline & c & 22.42 & 11.45 & 2.01 & 0.81 & 10.97 & 9.44 & 1.20 & 51.07 & 17.55 & 3.61 & 3.61 & 42.11 \\
\hline & D1 & 77,98 & 55.35 & 0.27 & 0.06 & 22.63 & 55,08 & 0.21 & 70.98 & 0.48 & 0.07 & 0.07 & 70.64 \\
\hline & D2 2 & 79.35 & 70.25 & 0.21 & 0.04 & 9.10 & 70.04 & 0.17 & 88.5 .3 & 0.30 & 0.015 & 0.05 & 88.27 \\
\hline & A & 22.12 & 6.56 & 1.75 & 1.23 & 15.56 & 4.81 & 0.52 & 29.67 & $26.66 \%$ & 5.58 & 5.58 & 21.76 \\
\hline & AE & 21.14 & 10.95 & 4. 40 & 1.54 & 10.19 & 6.55 & 2.86 & 51.79 & 40.19 & 7.26 & 7.26 & 3090 \\
\hline & $\mathrm{Bfe} B b r$ & 37.82 & 13.07 & 6.37 & 2.78 & 24.75 & 6.70 & 3.59 & 34.55 & 48.74 & 7.35 & 7.35 & 17.71 \\
\hline & c & 32.12 & 12.63 & 4.36 & 1.23 & 19.49 & 8.27 & 3.13 & 39.32 & 34.52 & 3.83 & 3.83 & 25.75 \\
\hline & D) & 75.78 & 56.56 & 1.27 & 0.09 & 19.22 & 55.80 & 1.18 & 74.64 & 2.24 & 0.11 & (3.111 & 72.97 \\
\hline & $\mathrm{D} 2$ & 79.32 & $71 . .31$ & 0.93 & 0.04 & 8.01 & 70.38 & 0.89 & 89.90 & 1.30 & 0.015 & 0.05 & 88.73 \\
\hline \multirow[t]{8}{*}{ Inceptisols } & A & 27.23 & 6.98 & 3.98 & .324 & 201.25 & 3.00 & 0.74 & 25.6 .3 & 5698 & 11.89 & $4(6.39$ & 11.0 .3 \\
\hline & $13 \mathrm{fe}|3| \mathrm{r}$ & 49.78 & 21.04 & 6.27 & 3.50 & 28.74 & 14.77 & 2.77 & 42.27 & 29.79 & 7.03 & 16.63 .3 & 29.67 \\
\hline & c1 & 50.12 & 24.61 & 2.69 & 0.71 & 25.51 & 21.91 & 1.99 & 49.10 & 10.95 & 1.41 & 2.88 & 43.72 \\
\hline & $C^{2}$ & 51.23 & 24.45 & 2.23 & 0.23 & 26.78 & 22.22 & 2.000 & 47.73 & 9.12 & 0.45 & 0. 45 & 43.37 \\
\hline & A & 31.4 .5 & 10.98 & $8.66 \%$ & 3.71 & 20.47 & 2.32 & 4.94 & .34 .91 & 78.83 & 11.81 & $11 . x 1$ & 7.39 \\
\hline & $\left|3 \mathrm{fe}^{2}\right| 3 \mid x$ & 52.21 & 21.04 & 7.23 & 6.93 & 31.17 & 1.381 & 0.31 & 40,30 & .34 .37 & 1.326 & 13.26 & 26.45 \\
\hline & c1 & 54.67 & 24.61 & 1.14 & 0.99 & 30.06 & 23.47 & 0.14 & 45.02 & 4.63 & 1.82 & 1.82 & 42.93 \\
\hline & 02 & 54.34 & 24.23 & 0.87 & 0.45 & 30.11 & 23,36 & 0.42 & 44.59 & 3.59 & 0.83 & 0.83 & 42,99 \\
\hline
\end{tabular}

weathering of the primary minerals, as well as to the extent to which pedogenic processes are advanced (Mokma and Buurman 1982; Bednarek and Pokojska 1996; Degorski 2007). In all of the profiles studied, values are highest in the parent rock, accounting for between $45 \%$ of total iron content in Alfisols, up to more than $70 \%$ in Ultisols. The total content of free aluminium (Ald) is much lower than that of free iron, while the distribution down the studied soil profiles is more even (Table 1). Also of value in assessing the degree of weathering of material (and the age of a soil) is the content of silicate forms of iron (Feas) and aluminium (Alas), these being determined as the difference between the total content of iron $\left(\mathrm{Fe}_{t}\right)$ and the content of free iron $\left(\mathrm{Fe}_{\mathrm{d}}\right)$ and characterising that part of the aluminium or iron that does not transfer down through the soil profile in the weathered soil substratum (Mokma and Buurman 1982; Mocek 1988, Karltun et al. 2000; Degorski 2002). In the soils studied, the content is greatest in the enrichments horizons and in the parent rock.

Taken to indicate fresh precipitation, an amorphous or so-called weakly-ordered structure for the oxides of iron (Feo) and aluminium (Alo) extracted in an oxalate reagent (Tamm 1922, 1932; McKeague et al. 1971; Gustafsson et al. 1998; Hees et al. 2000 ) attains the highest value in any of the studied soils in the enrichment horizon. Figures are in turn lower than for free iron and free aluminium in all horizons (Tables 1,2 ). Some of the compounds of iron not associated with silicates are present in crystalline form (Mokma and Buurman 1982; Kartlun et al. 2000), these being characterised in 
Table 2. Content of different forms of aluminium and relationship between them in the studied Ultisols and Inceptisols

\begin{tabular}{|c|c|c|c|c|c|c|c|c|c|c|}
\hline \multirow{3}{*}{ Soil type } & \multirow{3}{*}{ Inorizon } & \multirow{2}{*}{ Alt } & \multirow{2}{*}{ Ald } & \multirow{2}{*}{ Alo } & \multirow{2}{*}{ Alp } & Alas & Akr & Alac & \multirow{2}{*}{$-\Lambda \mathrm{ld} \cdot \Lambda \mathrm{It}^{-1}$} & \multirow{2}{*}{ Alo $: \mathrm{Nld}^{-1}$} \\
\hline & & & & & & Alt-Ald & Ald-Alo & $A \mid O-A l_{p}$ & & \\
\hline & & g. $\mathrm{kg}^{-1}$ & & & & & & & $\not z$ & \\
\hline \multirow[t]{12}{*}{ Ultisols } & $\Lambda$ & 28.75 & 0.75 & 0.67 & 0.25 & 28.00 & 0.08 & 0.42 & 2.62 & 88.90 \\
\hline & $\Lambda$ & 43.61 & 1.43 & 1.18 & 0.78 & 42.18 & 0.26 & 0.40 & 3.28 & 82.13 \\
\hline & I le e I3trr & 41.56 & 2.05 & 1.89 & 1.61 & 39.51 & 0.16 & $0.2 x$ & 4.93 & 92.32 \\
\hline & $c$ & 39.20 & 1.99 & 1.57 & 0.3 .3 & .37 .21 & 0.42 & 1.24 & 5.08 & 78.89 \\
\hline & D1 & 70.98 & 3.78 & 1.01 & 0.12 & 67.20 & 2.77 & 0.89 & 5.33 & 26.72 \\
\hline & $\mathrm{D} 2$ & 78.90 & 4.56 & 0.99 & 0.12 & 74.34 & 3.57 & 0.87 & 5.78 & 21.71 \\
\hline & $\Lambda$ & 29.67 & 2.75 & 1.47 & 0.56 & 26.92 & 1.28 & 0.92 & 9.28 & 53.39 \\
\hline & $\Lambda \Sigma$ & 51.79 & 2.43 & 1.48 & 0.86 & 49.36 & 0.96 & 0.61 & 4.70 & 60.70 \\
\hline & I3leI3tor & 34.55 & 2.05 & 1.61 & 1.06 & .32 .50 & 0. 44 & 0.54 & 5.93 & 78.58 \\
\hline & C & 36.45 & 1.92 & 1.23 & 0.98 & .34 .53 & (1).69 & 0.25 & 5.27 & $(44.0) 6$ \\
\hline & $\mathrm{D} 1$ & 74.64 & 1.72 & 0.56 & 0.31 & 72.92 & 1.16 & 0.25 & 2.31 & 32.66 \\
\hline & $\mathrm{D} 2$ & 80.12 & 1.78 & 0.65 & 0.23 & 78.34 & 1.13 & 0.42 & 2.22 & 36.52 \\
\hline \multirow[t]{8}{*}{ Ineeptisols } & $\Lambda$ & 25.63 & 2.56 & 1.92 & 1.80 & 23.08 & 0.63 & 0.13 & 9.98 & 75.24 \\
\hline & I3tr & 42.27 & 6.75 & 4.1) 2 & 2.86 & 3.5 .51 & 2.73 & 1.17 & 15.97 & 59.59 \\
\hline & C! & 49.10 & 2.14 & 0.82 & 0.58 & 46.96 & 1.32 & 0.24 & 4.36 & 38.41 \\
\hline & $\mathrm{C} 2$ & 54.20 & 3.43 & 1.09 & 0.50 & 50.77 & 2.34 & 0.59 & 6.33 & 31.78 \\
\hline & $\mathrm{A}$ & 34.91 & 1.80 & 1.75 & 2.15 & 3.3 .11 & 0.05 & -0.40 & 5.15 & 97.35 \\
\hline & $\mathrm{Bbr}$ & 40.30 & 4.02 & 2.39 & 2.86 & 36.28 & 1.63 & -0.46 & 9.98 & 59.52 \\
\hline & $\therefore$ & 45.02 & 2.14 & 0.82 & 0.58 & 42.87 & 1.32 & 0.24 & 4.76 & 38.41 \\
\hline & $\mathrm{C}_{2}$ & 49.34 & 4.15 & 1.39 & 0.51 & 45.19 & 2.76 & 0.88 & 8.41 & 33.49 \\
\hline
\end{tabular}

terms of the difference between the content of free iron (Fed) and forms of amorphous or organic iron (Feo). The soil contents of iron in this form are first and foremost influenced by the age of the soil, if also by the climate, since this conditions the type and rate of weathering, as well as pedogenic processes and factors hindering crystallization that include a more major humus content, as well as the presence of phosphate or silicate ions (Bednarek and Pokojska 1996, Degorski 2007). In all the soils studied, the shares of iron in crystalline form achieve their greatest values in the parent rock, ranging from between $21.9 \%$ in Inceptisols, through to more than $55 \%$ in underlying rock of Ultisols (Table 1).

Present in iron/aluminium-humus complexes, certain organic forms of iron and aluminium (respectively Fep and Alp) are transferred through the profile, mainly through podzolization, exerting a direct influence on the sequence of genetic horizons and their properties (Alexandrova 1960; McKeague 1967; Mokma and Buurman 1982; Bednarek 1991). All the soils studied showed clearly elevated contents of the latter in the enrichment horizon, most especially in red-yellow podzolic soils (Ultisols) and grey-brown podzolic soils (Alfisols). Likewise, the enrichment horizons had the greatest contents of inorganic forms of iron and aluminium (Feac and Alac), these being derivatives of the oxalate and pyrophosphate forms (Tabe 1 and 2). The presence of the latter in the soil is important on account of their marked affinity for other organic and inorganic chemical compounds (notably phosphates and silicates), as well as the formation of soluble Fe-Al complexes and their transfer down the profile in the form of sols of aluminium with silica as proto-imogolite (Farmer et al. 1980; Farmer and Fraser 1982; Lumsdon and Farmer 1995; Gustafsson et al. 1995, 1998, 1999; Lundstrom et al. 2000). 
Table 3. Content of amorphous iron and aluminium in the enrichment horizon (mean values), according to WRB

\begin{tabular}{lll}
\hline Soil type & Soil horizon & $\mathrm{Alo}+1 / 2 \mathrm{Feo}$ \\
\hline Ultisols & $\mathrm{BhfeBbr}$ & 0.39 \\
Inceptisols & $\mathrm{BfeBbr}$ & 0.66 \\
Alfisols & $\mathrm{Bt}$ & 0.60 \\
\hline
\end{tabular}

The defined indicators of the advancement of leaching and/or podzolization in the studied soils show that all have been subject to the said processes, if at varying intensities. A more complex issue is the unequivocal assessment of the type of process that has been taking place. The indicator involving the content of amorphous iron and aluminium in the enrichment layer - as expressed in terms of the total for amorphous aluminium (Alo) and half of the content for amorphous iron (Feo) - points to the most intensive process of podzolization characterising the Inceptisols and Alfisols, which meet the criteria from the WRB $(1998,2006)$ for podzolic soils (Table 3 ). However, none of the soils studied are found to meet the said diagnostic criteria if reference is made to the ratio between the content of amorphous aluminium (Alo) and $1 / 2$ that of amorphous iron (Feo) in the eluvial and enrichment horizons - (Alo $+0.5 \mathrm{FeoB}) /(\mathrm{Alo}+0.5 \mathrm{FeoE})$. The proposal from the WRB $(1998,2006)$ holds that the minimum allowable value for this indicator in podzolic soils is 2 - suggesting that the diagnostic spodic horizons need to have at least twice as much iron and aluminium in amorphous forms as does the eluvial horizon. In our soils, this index in fact assumes values in the range 1.31 (in the case of Ultisols) to 1.82 (Inceptisols) - Table 4.

The index of the degree of illuviation (Wi) - defined by Mokma (1983) as: $\Sigma$ B Cp Alp Fep - $\sum$ A Cp Alp Fep - also points to the leaching of all the studied soil profiles, notwithstanding the marked diversity of values obtained for it, ranging from 1.07 in the case of Inceptisols, 1.48 in Alfisols to 2.04 in Ultisols. The fact that intensive illuviation is ongoing in Alfisols and Ultisols is also confirmed by the indicator reflecting the transfer of free iron, i.e. $\mathrm{Wp}_{\mathrm{Fe}}$ - defined as the ratio of $\mathrm{Fd}$ content in two adjacent genetic horizons (either the humus and eluvial layers, or the eluvial layer and spodic horizon). In this case, all soils analysed gave values greater than 1 , denoting enrichment layers with greater contents of free iron than their overlying horizons. However, the wide range

Table 4. Values of indices for characteristic of podzolization process criteria

\begin{tabular}{|c|c|c|c|c|c|c|c|c|}
\hline \multirow{4}{*}{ Soil type } & \multirow{4}{*}{ l'sot $^{\prime} \mathrm{x}$} & \multirow{3}{*}{$\frac{\mathrm{Al}+1 / 2 \mathrm{Fc}_{\mathrm{o}} \mathrm{B}}{\mathrm{F}}$} & \multirow{3}{*}{$\begin{array}{l}\mathrm{Al}+1 / 2 \mathrm{Fe}_{\mathrm{o}} \mathrm{B} \\
\mathrm{Al}+1 / 2 \mathrm{Fe}_{\mathrm{o}} \mathrm{L}\end{array}$} & \multirow{3}{*}{$\begin{array}{l}\operatorname{lic}_{\mathrm{d}} \mathrm{I3} \\
\operatorname{lic}_{\mathrm{d}} \mathrm{E}\end{array}$} & \multirow{3}{*}{$w_{i}$} & \multirow{2}{*}{$\mathrm{C}_{\mathrm{F}}+\mathrm{Al}_{\mathrm{p}}+\mathrm{Fe}_{\mathrm{F}} \mathrm{B}$} & $\mathrm{C}_{\mathrm{p}}+\mathrm{Al}_{\mathrm{p}}+\mathrm{Foc}_{\mathrm{p}} \mathrm{B}$ & \multirow{3}{*}{$\begin{array}{l}\text { CPB } \\
\text { Alp +FepB }\end{array}$} \\
\hline & & & & & & & $\mathrm{C}_{\mathrm{p}}+\mathrm{Al}_{\mathrm{p}}+\mathrm{li} \mathrm{e}_{\mathrm{p}} \mathrm{A}$ & \\
\hline & & & & & & $\%$ & & \\
\hline & & a & b & c & $\mathrm{d}$ & e & i & $g$ \\
\hline \multirow[t]{2}{*}{ Ultisols } & 1 & 0.30 & 1.74 & 1.07 & 2.04 & 5.63 & 1.57 & 13.1 \\
\hline & 2 & 0.48 & 1.31 & 1.19 & 1.27 & 6.13 & 1.24 & 17.4 \\
\hline Inceptisols & 1 & 0.71 & 1.82 & 3.01 & 1.07 & 1.34 & 1.01 & 4.9 \\
\hline Alfisols & 1 & 0.61 & 1.14 & 1.91 & 1.48 & 1.46 & 1.11 & 3.4 \\
\hline
\end{tabular}

Explanatory notes:

a. content of amorphous iron and aluminium in the enrichment horizon, according to WRB (1998)

b. index of the transfer of amorphous forms of iron and aluminium, according to WRB (1998)

c. index for the transfer of free iron, according to Konecka-Betley (1968) and Bednarek (1991)

d. index of illuviation (Wi) according to Mokma (1983)

e. iron-aluminium-humus complexes in B horizon, according to Mokma (1983)

f. relationships ongoing between the contents of iron-aluminium-humus complexes in the humus horizon and the diagnostic spodic horizons according to Mokma (1983)

g. characteristics of immobile complexes according to Mokma (1983). 
of values for the index suggest that free iron is transferred with varying intensities in the different kinds of soil studied (Table 1).

A further important diagnostic criterion in evaluating podzolization processes is the molar ratio of organic carbon to total aluminium and iron as determined in pyrophosphate extract. According to D. Mokma (1983), a value for this ratio greater than 5.8 (but less than 25) characterises complexes that become immobile, these values being typical for the spodic horizons in podzolic soils. In the enrichment layers of the Inceptisols and Alfisols under analysis, molar ratios obtained for $\mathrm{Cp} /(\mathrm{Alp}+\mathrm{Fep})$ do not meet the criterion in question, the value for the indicator ranging between 3.4 and 4.9 , thereby pointing to partial lability in the $B$ horizon. Only in the enrichment layers of the Ultisols ratios obtained for $\mathrm{Cp} /(\mathrm{Alp}+\mathrm{Fep})$ is higher them 5.8. On the other hand, all of the soils studied show conformity with a criterion based on estimates of the content of iron/ aluminium-humus complexes in the enrichment layer, as these are determined where samples are extracted in sodium pyrophosphate (Mokma, 1983). The value in question in the enrichment layer in all studied soil types was above $0.5 \%$ of complex humus linkages with $\mathrm{R}_{2} \mathrm{O}_{3}$ (Table 4).

All of the soils studied also meet a criterion based on the relationships ongoing between the contents of iron/aluminium-humus complexes in the humus and enrichment layers, inasmuch as that the latter are greater than the former. It nevertheless needs to be emphasized that the differences in question are very small (Table 4).

\section{FORMS OF IRON AND ALUMINIUM AS INDICATORS OF ENVIRONMENTAL DEVELOPMENT}

On the basis of the contents of different forms of iron and aluminium - as well as the mutual relationships between them - it is possible, not only to assess the courses of pedogenic processes, but also to draw conclusions regarding the conditioning underpinning a giv- en area's development. One of the elements in such an assessment is the relative age of lithological material in the stratigraphic sequences of sediments. Identification of the relative age of the substratum makes use of the content of iron in crystalline forms (Fecr), determined in terms of differences between the content of free oxides of iron (Fed) and that of amorphous forms (Feo), such differences being related to the progressing weathering of parent material. Such an analysis is possible in the case of lithological material of similar total iron content, where the products of weathering are dependent on the duration of exogenous and pedogenic processes. The older the soil, the more likely it is to feature a higher Fecr content. The obtained results for the content of iron in crystalline forms in red-yellow podzolic soils (Ultisols) point to differences in the age of substratum sedimentation in profiles. The soil substratum is shown to be much older than the superficial slope covers in which it was developed. In the oldest slope covers, values for the indicator of the content of total iron that is in the form of crystalline oxides are close to 0,9 , while they do not exceed 0,45 in the soil solum - this despite the fact that contents of crystalline iron compounds in soil profiles developed on superficial lithological layers are influenced by pedogenic processes as well as exogenous ones (Fig. 2).

In the podzolized brown acid soils (Inceptisols) developed in the uniform youngest covers of the Meghalaya Plateau, the values for the indicator constituted by content of crystalline iron oxides as set against total iron content are very similar, assuming values in excess of 0.4 in the parent-rock and substratum layers. In line with the different soil types, there are also differences in characteristics determined for the various genetic horizons (Fig. 3).

To compare the extents to which material in soil profiles had been weathered, use was also made of an indicator determined using the Fed:Fet ratio (Bednarek and Pokojska 1996). This reaches maximum values close to $100 \%$ in old detritus forming under the conditions of a hot and humid climate, allowing 


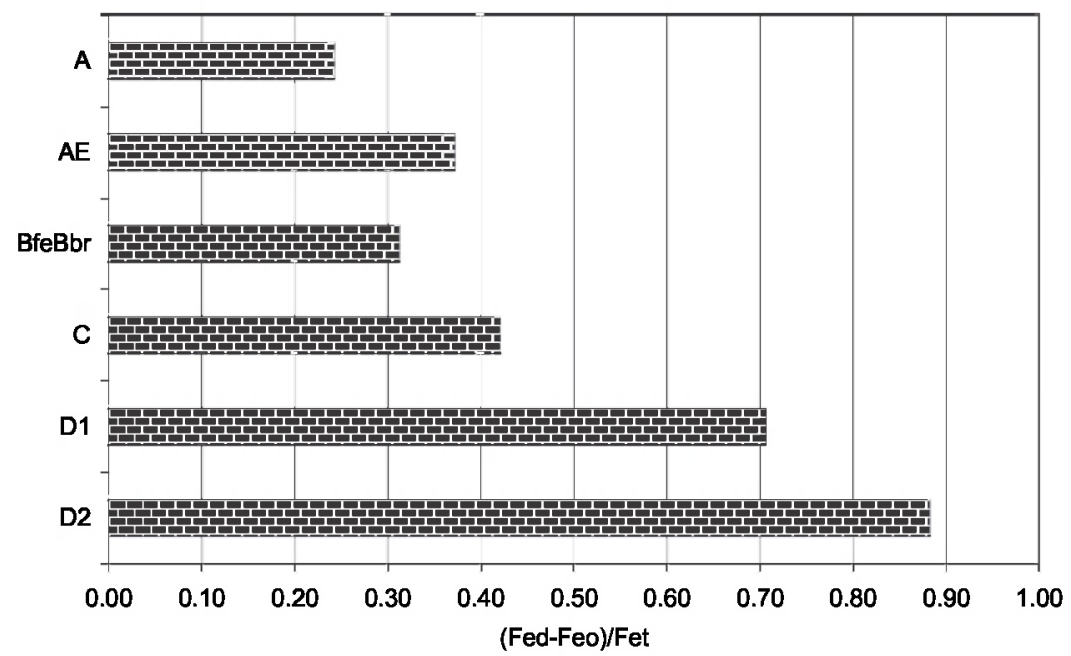

Figure 2. Index for the content of crystalline iron oxides in total iron in Ultisols and their parent rock developed in slope caps of the Meghalaya Upland (India)

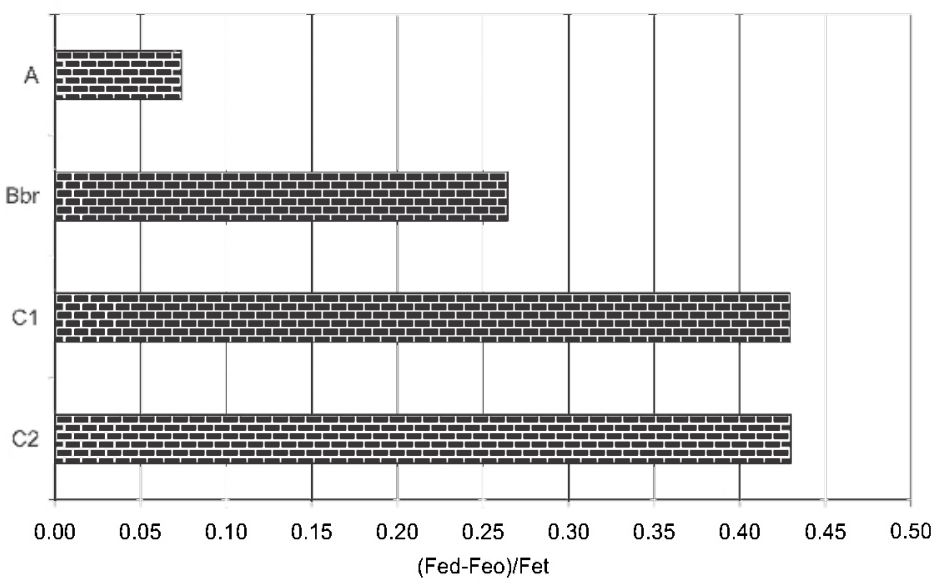

Figure 3. Index for the content of crystalline iron oxides in total iron content in Inceptisols and their parent rock developed in the youngest slope caps of the Meghalaya Upland (India)

almost all of the iron silicates to converted to oxides. In the Ultisols under study, the substratum layer developed in the oldest of the slope covers analysed was characterised by a value for the coefficient close to $90 \%$, this without doubt suggesting a marked impact of exogenous and pedogenic factors on the lithological material (Fig. 4).

Freshly precipitated oxides of iron, most often formless or weakly crystalline, are gradually made subject to an ageing process whereby they become dewatered and crystallised (Bednarek and Pokojska 1996). The degree of advancement of these processes is assessed by reference to the ratio of amorphous-form iron (Feo) to Fed-form iron, this being considered indicative of oxide activity (Schwertmann 1964). A high value for the ratio, obtained where soils develop under similar climatic conditions, 
attests to the young age of lithopedogenic material, while a low value points to a long period of impact of weathering processes following the completed sedimentation of geological material. As with the indicator involving contents of crystalline oxides, differences for iron oxide activity within a soil profile reflect the soil process and the ge- netic horizons arising as a result of it. This relationship is presented very effectively in terms of the profile-related differentiation to values in cross-sections for slope cover of the Meghalaya Plateau, the substratum there being much older than the cover material in which today's soil has developed (Fig. 5).

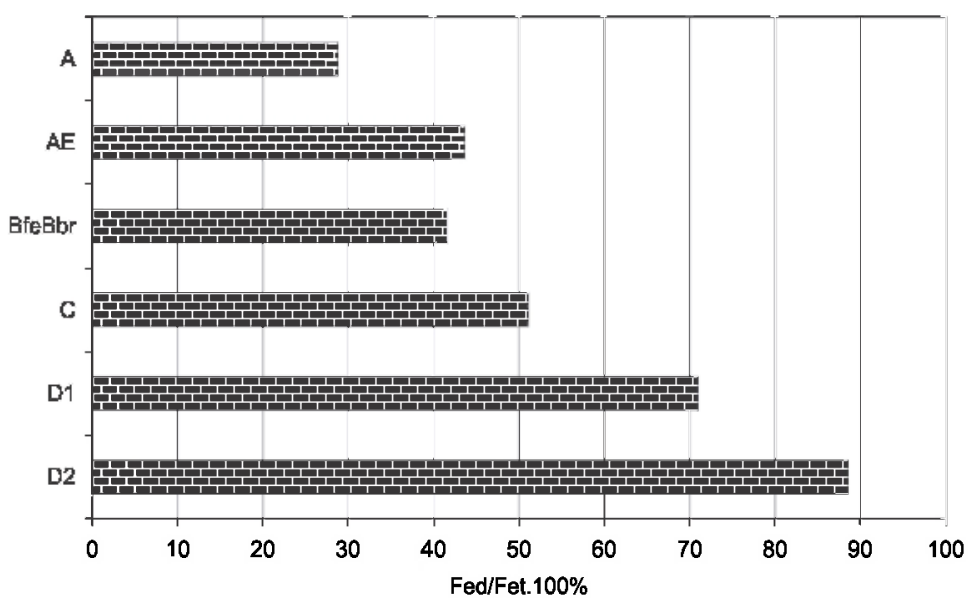

Figure 4. Index for the content of free iron (Fed) in the total content of iron (Fet) in Ultisols and their parent rock developed in slope caps of the Meghalaya Upland (India)

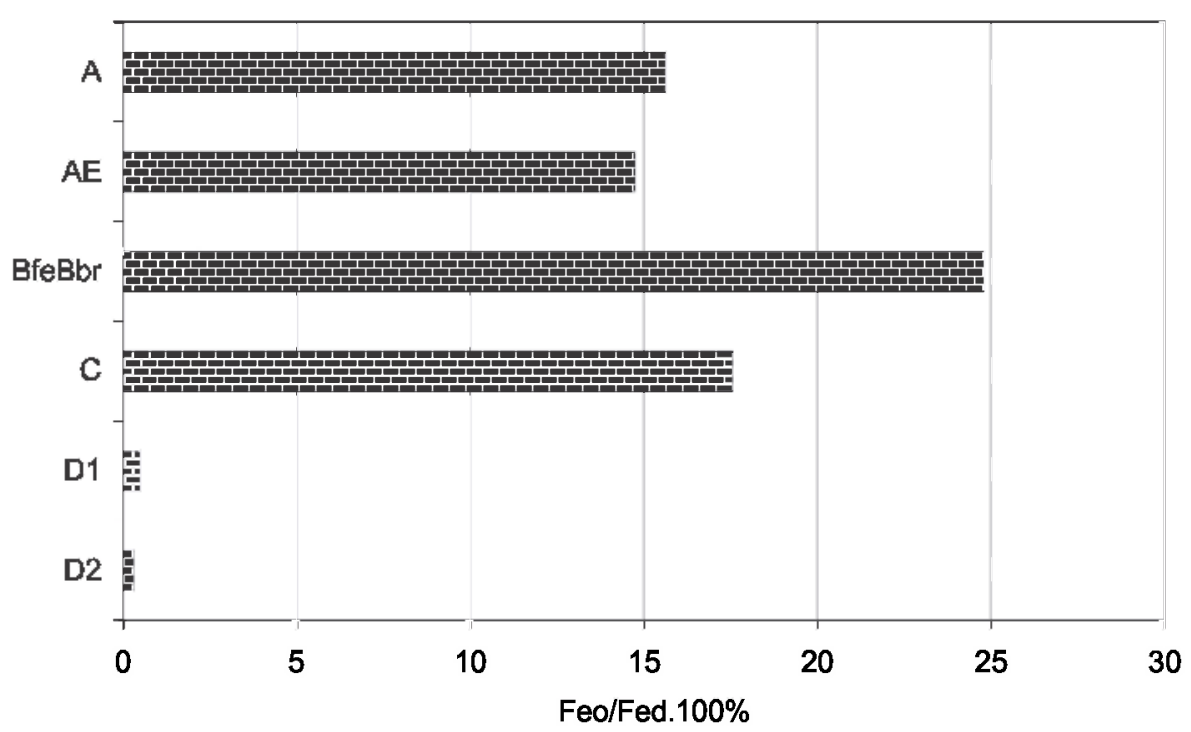

Figure 5. Index of iron oxide mobility for soils and their parent rock developed in slope caps of the Meghalaya Upland (India) 


\section{SUMMARY}

The results obtained confirm the advanced research hypothesis that the contents of different forms of iron and aluminium in soils are of considerable indicative value when it comes to interpreting the courses of pedogenic processes and the environmental conditioning that underpinned soil-cover development. The indicators selected allowed it to be determined that all soils studied show signs of profile leaching - something that can be associated with precipitation totals and infiltration of the water that are periodically and connected with summer monsoon. Equally, none of the criteria advocated by Mokma (1983) as distinguishing the typological group of podzolic soils were met by any of the soils studied. The most advanced processes of podzolization are characteristic for the red-yellow podzolic soils (U1tisols) in which the index involving immobile iron-aluminium complexes (Mokma 1983) has a value is typical for the spodic horizon. Podzolic acid brown soils (i.e. Inceptisols), in which the index involving immobile iron-aluminium complexes (Mokma 1983) has a value approaching 5 , while the index for the content of amorphous iron and aluminium in the illuvial horizon exceeds $0.5 \%$ by weight in the soil. Other soil types reveal less intensive podzolization processes, albeit ones whose existence is nevertheless confirmed - by at least of the diagnostic criteria defined.

A further thesis advanced and gaining confirmation concerns the indicative value of different forms of iron and aluminium in soils - and the interrelationships between them - when it comes to interpreting the environmental conditioning that has underpinned pedogenesis. The indicators were found to offer a very suitable means of interpreting differences in the relative ages of different sedimenting layers, and the time of onset of soil-generating processes, and they also facilitate the "re-creation" of the external agents that conditioned soil-cover development, not least hygrothermic properties of the climate determining processes destructive of the substratum, as well as pedogenic ones $-i . a$. the processes of illuviation, leaching and podzolization reported from the soils studied.

\section{ACKNOWLEDGEMENTS}

This research was financed by the Ministry of Science and Higher Education in Warsaw (Poland), within the framework of Project No. 2P04E 02927 entitled "The structure and long-term course to rainfall in the India's Cherrapunji district and Shillong University".

\section{REFERENCES}

Alexsandrova, L.N., (1960), Use of sodium pyrophosphate for the extraction of free humic substances and their organomineral compounds from soil, Pochvovedeniye, 2: 90-97.

Arduino, E., Barberis, E., Ajmone-Marsan, F., Zanini, E., Franchini, M. (1986), Iron oxide and clay minerals within profiles as indicators of soil age in northern Italy, Geoderma, 37: 45-55.

Bednarek, R. (1991), Wiek, geneza i stanowisko systematyczne gleb rdzawych $w$ swietle badan paleopedologicznych w okolicach Osia, Bory Tucholskie [Age, genesis and systematic position of rusty soil on the basis of paleopedological study in Osie, Bory Tucholskie]. Rozprawy UMK, Toruń.

Bednarek, R., Pokojska U. (1996), Diagnostyczne znaczenie niektórych wskaźników chemicznych w badaniach paleopedologicznych [Diagnostic value of some chemical indices in paleopedological study], Konferencja „Metody bađań paleopedologicznych i wykorzystanie gleb kopalnych w paleopedologii", Lódź 26-28 June 1996, Komisja Paleopedologii Komitetu Badań Czwartorzędu PAN, Uniwersytet Łódzki, Łódź, 25-29.

Blume, H., Schwertmann, U. (1969), Genetic evaluation of profile distribution of aluminum, iron and manganese oxides, Soil Science Society of America Proceedings, 33: 438-444.

Borggard, O. (1976), Selective extraction of amorphous iron oxide by EDTA from the mixture 
of amorphous iron oxide, goethite, and hematite, Journal of Soil Science, 27: 478-486.

Budek, A., Prokop, P. (2005), Mikromorfologiczne cechy pokryw glebowych obszaru o najwyższych opadach na świecie - Cherrapunji, Wyżyna Meghalaya, Indie [Micromorphological features of soil in the region of highest precipitation in the world - Cherapunji, Meghalaya, India], Przeglad Geologicz$n y, 53,4: 293-298$.

Catt, J. (1988), Quatemary geology for scientist and engineers, John Wiley and Sons, New York-Chichester-Brisbane-Toronto.

Degórski, M. (2002), Przestrzenna zmienność właściwości gleb bielicoziemnych środkowej i północnej Europy a geograficzne zróżnicowanie czynników pedogenicznych [The spatial variability to the properties of podzolic soils in Central and Northern Europe and the geographical differentiation of pedogenic factors], Prace Geograficzne, 182, Instytut Geografii i Przestrzennego Zagospodarowania (IGiPZ), PAN.

Degórski, M. (2007), Spatial variability in podzolic soils of Central and Northern Europe, U.S. Environmental Protection Agency, Washington, D.C.

Farmer, V., Russell, J., Berrow, M. (1980), Imogolite and proto-imogolite allophane in spodic horizons evidence for a mobile aluminum silicate complex in podzol formation, Journal of Soil Science, 31: 673-684.

Farmer, V., Fraser, A. (1982), Chemical and colloidal stability of sols in the $\mathrm{Al}_{2} \mathrm{O}_{3}-\mathrm{Fe}_{2} \mathrm{O}_{3}-$ $\mathrm{SiO}_{2}-\mathrm{H}, \mathrm{O}$ system: their role in podzolization, Journal of Soil Science, 33: 737-742.

Fridland, V. (1957), Podzolization and illmerization, Dokuchaev Soil Science Institute, Soviet Union, Doklady Akademii Nauk, 115: 10061009.

Giesler, R., Ilvesniemi H., Nyberg L., Hees P., Starr M., Bishop T., Kareinen T., Lundsrtrom U. (2000), Distribution and mobilization of Al., Fe and $\mathrm{Si}$ in three podzolic soil profiles in relation to the humus layer, Geoderma, 94 : 249-263.

Gustafsson J., Bhattacharya, P., Bain, D., Fraser, A., McHardy, W. (1995), Podzolization mechanisms and the synthesis of imogolite in northern Scandinavia, Geoderma, 66: 167-184.
Gustafsson, J., Bhattacharya, P., Karltun, E. (1999), Mineralogy of poorly crystalline aluminium phases in the $\mathrm{B}$ horizon of Podzols in southern Sweden, Applied Geochemistry, 14 . 6: 707-718.

Gustafsson, J., Lumsdon, D., Simonsson, M. (1998), Aluminum solubility characteristics of spodic B horizons containing imogolite-type materials, Clay Minerals, 33: 77-86.

Hess, P., Lundström, U. (2000), Equilibrium models of aluminum and iron complexation with different organic acids in soil solution, Geoderma, 94: 201-221.

Karltun, E., Bain, D., Gustafsson, J., Mannerkoski, H., Murad, E., Wagner, U., Fraser, A., Mc Hardy, W., Starr M. (2000), Surface reactivity of poorly-ordered minerals in podzol B horizons, Geoderna, 94, 265-288.

Konecka-Betley, K. (1968), Zagadnienia żelaza w procesie glebotwórczym [Iron in the soil process], Roczniki Gleboznawcze, 19, 1:51-97.

Lumsdon, D., Farmer, V. (1995), Solubility characteristics of proto-imogolite sols: How silicic acid can de-toxic aluminum solutions, European Journal of Soil Science, 46: 179-186.

Lundström, U., van Breemen, N., Bain, D. (2000), The podzolization process. A review, Geoderma, 94: 91-107.

Mazumdar, S. (1978), Morphogenetic evolution of the Khasi Hills, Meghalaya, Miscellaneous Publication, Geological Survey of India, 30: 208-213.

Mazumdar, S. (1986), The Precambrian framework of part of the Khasi Hills, Meghalaya, Records of the Geological Survey of India, 117, 2: $1-59$.

McKeague, J. (1967), An evaluation of 0,1 M pyrophosphate-dithionite in comparison with oxalate as extractants of the accumulation products in Podzols and some other soils, $\mathrm{Ca}$ nadian Journal of Soil Science, 47: 95-99.

McKeague, J. (ed.), (1981), Manual on soil sampling and methods of analysis, Canadian Society of Soil Science.

McKeague, J., Brydon, J., Miles, N. (1971), Differentiation of forms of extractable iron and aluminium in soils, Soil Science Society of America Proceedings, 35: 33-38.

Mehra, O., Jackson, J. (1960), Iron oxide removal from soils and clays by a dithionite-citrate sys- 
tem buffered with sodium bicarbonate, Clay and Clays Minerals, 5: 317-327.

Melke, J. (1997), Niektóre prawidłowości w składzie chemicznym gleb brunatnych różnych regionów geograficznych [Some regularities in chemical compositions of brown soils in different geographical regions], Wydzial Biologii i Nauk o Ziemi, Rozprawy habilitacyine, 56. Wydawnictwo UMCS, Lublin.

Mocek, A. (1988), Żelazo w vertisolach i mollisolach okolic Shahrazoor i Raniya w półnono-wschodniej części Iraku [Iron in Vertisols and Mollisols of Shahrazoor and Raniy regions in north-ester part of Irak], Roczniki Gleboznawcze, 39, 3: 45-55.

Mokma, D. (1983). New chemical criteria for defining the spodic horizon, Soil Science of American Joumal, 47, 5: 972-976.

Mokma, D. (1991), Genesis of spodosols in Michigan, USA, Trends in Soil Science, 1: 25-32.

Mokma, D., Buurman, P. (1982), Podzols and podzolization in temperate regions, ISM Monograph 1, International Soil Museum, Wageningen, The Netherlands, $126 \mathrm{pp}$.

Petersen, L. (1976), Podzols and podzolization, Royal Veterinary and Agricultural University, Copenhegen.

Pokojska, U. (1979), Geochemical studies on podzolization. Part I. Podzolization in the light of the profile distribution of various forms of iron and âluminium, Roczniki Gleboznawcze, 30, 1: 189-215.

Prokop, P. (2007), Degradacja środowiska przyrodniczego południowego skłonu Wyżyny Meghalaya, Indie [Land degradation of the southern slope of the Meghalaya Plateau, India]. Prace Geograficzne 210, Instytut Geografii i Ptzestrzennego Zagospodarowania (IGiPZ), PAN.

Riise, G., Hess, P, Lundström, U., Strand, L. (2000), Mobility of different size fraction of organic carbon, Al., Fe, Mn, and $\mathrm{Si}$ in podzols. Geoderma, 94: 237-247.

Schwertmann, U. (1964), Differenzierung der Eisenoxide des Bodens durch Extraktion mit
Ammoniumoxalat-Losung, Zeitschrift für Pflanzenernährung, Düngung, Bodenkunde, 105: 194-202.

Soil Taxonomy (1999), A Basic system of soil classification for making and interpreting soil surveys, Soil Survey Staff United States Department of Agriculture. Agriculture Handbook Natural Resources Conservation Service Number 436.

Soja, R. (2004), The climate, in Starkel, L., Singh, S. (eds.), Rainfall, runoff and soil erosion in the globally extreme humid area, Cherrapunji region, India, Prace Geograficzne 191, Instytut Geografii i Przestrzennego Zagospodarowania (IGiPZ), PAN: 42-43.

Soja, R., Starkel L. (2007), Extreme rainfalls in Eastern Himalaya and southern slope of Meghalaya Plateau and their geomorphic impacts, Geomorphology, 84: 170-180.

Starkel, L. (1996), Present-day formation of the Southern part of Meglalaya Plateau, Hill Geographer, 12, 1-2: 13-19.

Systematyka Gleb Polski (1989), Polskie Towarzystwo Gleboznawcze, Roczniki Gleboznawcze 40, 3-4: 5-62.

Tamm, C. (1922), Om bestamning av de oorganiska componenterna i markens gelkomplex, Medd. Stattens Skogsforsoksanst, 19: 385-404.

Tamm, C. (1932), Uber die oxalatmethode in der chemichen bodenanalyse, Medd. Statens Skogsforsoksanst, 27: 1-20.

Van Reeuwijk, L. (1995) Procedures for soil analysis, Technical Paper. 9, International Soil Reference and Information Centre, Wageningen.

WRB (1998), World reference base for soil resources, World Soil resources Reports 84 , FAO, ISRIC and IUSS.

WRB (2006), World reference base for soil resources, A framework for international classification, correlation and communication, World Soil resources Reports 103, FAO, ISRIC and IUSS.

Paper first received: March 2011

In final form: October 2011 
http://rcin.org.pl 